\title{
Places of the Heart: Memorials, Public History and the State in Australia Since 1960
}

PAUL ASHTON AND PAULA HAMILTON

$\mathrm{T}$

This article draws on a national study of post-1960 non-war memorials, Places of the Heart, which was funded by an Australian Research Council Discovery Grant. ${ }^{1}$ Historically, the vast majority of memorials in Australia, and the academic study of them, has concerned men killed or serving in war and the use of memorials in war rituals - a dominant preoccupation of the Australian imagination. Despite the diversification and increase in types of other memorials since the 1960s, their placement, construction, meanings and utilisation are all to varying degrees framed by previous war memorials in Australian and other landscapes around the world. In turn, post World War I memorials have also drawn on traditional Christian symbolism which we now see perpetuated in vastly different forms such as roadside crosses and internet visual iconography. 
During the last twenty years there has been extensive public interest and concern in the forms and practices of war commemoration. Its most powerful international manifestation has been the emergence and public visibility of Shoah memorials in a range of countries and the literature which has emerged to understand and explain them materially, symbolically, politically and culturally. ${ }^{2}$ Those who have written on war commemoration and about particular memorials to World War I, World War II and - in Australia and the USA - Vietnam, have significantly advanced our understanding about commemoration as a cultural practice. In general, they have developed insights into the nature and meaning of memorialisation in a range of ways previously not considered. ${ }^{3}$ This extensive literature has been complemented in Australia by Ken Inglis' monumental work, Sacred Places: War Memorials in the Australian Landscape, which not only documents Australia's war memorials from the Boer war to Vietnam but provides a context for their analysis and interpretation. These range from increasingly harsh political environments - such as the post World War I period which saw conservatives use war memorials to buttress their power - to the 'cult of ANZAC' in a multicultural society experiencing globalization. ${ }^{4}$

The focus on war has been useful and important to understanding Australia's early embrace of the memorial to stand in for the absence of bodies after World War I, a war fought elsewhere, out of sight of most who would do the mourning for loved ones whose remains lay in battlefields or foreign graves. Less well understood, however, are the reasons for the emergence of a large number of other kinds of memorials in more recent years, reflecting a wider public desire to experience a process of commemoration through ceremonies of public ritual.

Chilla Bulbeck began to explore non-war (what she termed 'unusual') memorials in Australia during the 1980s and her survey work stands out in the field. ${ }^{5}$ A small number of other projects have been undertaken on memorials in Australia, some, as with Bulbeck's, in the lead up to the Bicentennial celebrations. The Royal Australian Historical Society's useful Bicentennial monuments and memorials project is the most substantial but it was essentially a documentary project. ${ }^{6}$ Apart from this, only specific case studies of particular memorials have been published. The most important of these was Bruce Scates and Rae Frances' work on contesting a traditional nineteenth-century explorer's memorial which honoured those who 
had killed Aborigines in the course of their expedition. Their study confronted the question of how a culture deals with memorials which become completely outdated and offensive to indigenous people. ${ }^{7}$

The majority of memorial studies, however, provide little historical context to the memorials themselves and how their meanings have changed over time. Our project argues that, particularly over the last twenty years, we need to be attentive to shifts in memorialisation as a cultural process of which memorials are one manifestation. There is not just a history of memorials as objects; there is a history of memory and commemoration and corresponding changes in their meaning. There are also other more concrete changes. Memorials have diversified considerably in form and purpose. They can be as much public sculpture now as purpose built in the traditional monumental way. There can be several reasons for the erection of memorials: as a means of uniting or bringing a community together; as a focus for commemoration; for the purpose of sacralising - or creating sacred spaces; as an aide to remembering an event or person; and more recently to make a political statement or to claim political ground, such as the recent SIEV X memorial in Canberra, which Julie Stephens argues is a form of protest against 'cultural forgetting'. ${ }^{8}$ But they almost always involve action where there is no body which differentiates them from cemeteries and graves. Indeed, Buchli and Lucas have argued 'that material culture shoulders the larger responsibility of our personal and collective memory'. ${ }^{9}$ As they among others have recognised, the corollary of this is that decay or destruction of these objects brings forgetfulness. As Melanie van der Hoorn has observed, forgetting and remembering 'is not a linear process but a struggle, a tension' which is consistent in all sites of public memory. ${ }^{10}$

Memorials have been previously studied through a range of cross disciplinary perspectives - including architecture, religion, anthropology, sociology and history - which variously emphasise materiality, conservation issues and textual relevance. Since the publication of Pierre Nora's three-volume Realms of Memory, ${ }_{1}^{11}$ where he introduced a notion of lieux de memoir - sites of memory - the academic study of memorials has been one of the most prolific of these 'sites of memory'. Commonly, authors draw on a single memorial as a metonym: it is made to stand in for all other memorials of this type; or charting its genealogy functions as an 
expression or reflection of particular historical tensions in the society. In other words, it is representative of something else. In one important sense memorials are easy to use - they are There, materially circumscribed and manageable for a small study. While there are now more studies of a whole category of memorials, individually they are often seen as symbols through which to explore society and culture or to analyse a memorial's political effects, aesthetic implications or the responses it publicly elicits.

We are charting two particular trends evident in these changes that we have called 'retrospective commemoration' and 'participatory memorialisation'. These are not necessarily mutually exclusive. The first refers to the effort of state authorities at all levels to express a more inclusive narrative of the nation as a result of, among other things, multicultural policies by retrospectively commemorating a wider number of communities and people who have contributed to Australia's 'national development' and who have been chosen for that purpose. The second refers to a range of vernacular memorials initiated by groups or individuals which have been later taken up or taken over by government authorities or which have been sustained over short or long periods of time in conflict with them. These can range from the ephemeral - memorials on the spot of violent death or graffiti - to a more formal institution of commemorative plaques.

One of the most important shifts in the practice of memorialising from the late twentieth century has been the placing of memorials at the place and moment of death. This is particularly evident with roadside memorials which confront viewers with reminders of death in a culture which has often hidden it away. This, indeed, is one of the reason why roadside sites are sometimes contested. As Azaryahu argues, the 'spontaneous formation of memorial space' in this way makes heritage concrete in terms of its location so the intangible 'sense of place' becomes a space of tangible significance. ${ }^{12}$ But this does not solve the problem of competing demands for the meaning of those spaces, especially if they are part of the everydayness of people's lives.

That the state continues to intervene in the regulation of memoralisation is evident in a cultural industry which is rarely linked to it - heritage. How does the practice of setting up memorials relate to the sphere of state activity related to preservation of cultural heritage? Memorials remain amongst the most contested and enduring forms of public history. And they are both central to 
cementing shared cultural meanings about the past and sometimes blunt statements difficult to ignore. As material culture embedded in the landscape, their meanings inevitably change over time between generations and social groups. ${ }^{13}$ This has important implications for how we interpret and conserve them as the remains of the past. What do we do with memorials that become offensive or are no longer relevant? We are often ill at ease with their desecration or destruction because they serve as a lasting visual referent or 'anchor points' for former mentalities or previous acts of remembrance. ${ }^{14}$

State classificatory taxonomies and heritage listings of memorials have traditionally shaped what is considered significant and worthy of remembrance. ${ }^{15}$ But there is an interaction between official paradigms and popular forms of memoralisation out of which emerge shifts in understandings of the past and changes to rituals and meanings in relation to memorials.

Since the Granville train disaster in Sydney on 18 January 1977, for example, survivors and the relatives of those who died have thrown roses on the track each year, gradually meeting more cohesively as a group. On the day of the disaster, after an emergency two-hour Cabinet meeting, the New South Wales (NSW) State Government announced that a full judicial inquiry would be held into the tragedy. ${ }^{16}$ The NSW Coroner finally found that poor public track maintenance combined with bad track geometry and an excessive speed limit on the curve had caused Australia's worst rail calamity. Might political embarrassment or shame explain the absence for many years of official memorials at the site? Or may it be that at the time official memorialisation of such an event was not usual? In 1998 a memorial granite wall with the names of the 83 people killed was privately erected with official local government permission. Granville Council subsequently set up a memorial garden in a nearby park and on 15 January 2007 a plaque was unveiled on Granville Station concourse. Every year the anniversary ceremony attracts a larger number of people. It has also become more institutionalised. ${ }^{17}$

Formal, large scale and officially endorsed or sponsored memorials to the victims of the Bali terrorist bombing on 12 October 2002, which killed 202 people including 91 Australians, have also been erected in different states. Between 2004-5, a memorial fountain with 91 jets representing each life lost was constructed in Swanston Street, Carlton, in Victoria. (The plaque noted that twenty- two of the victims were 


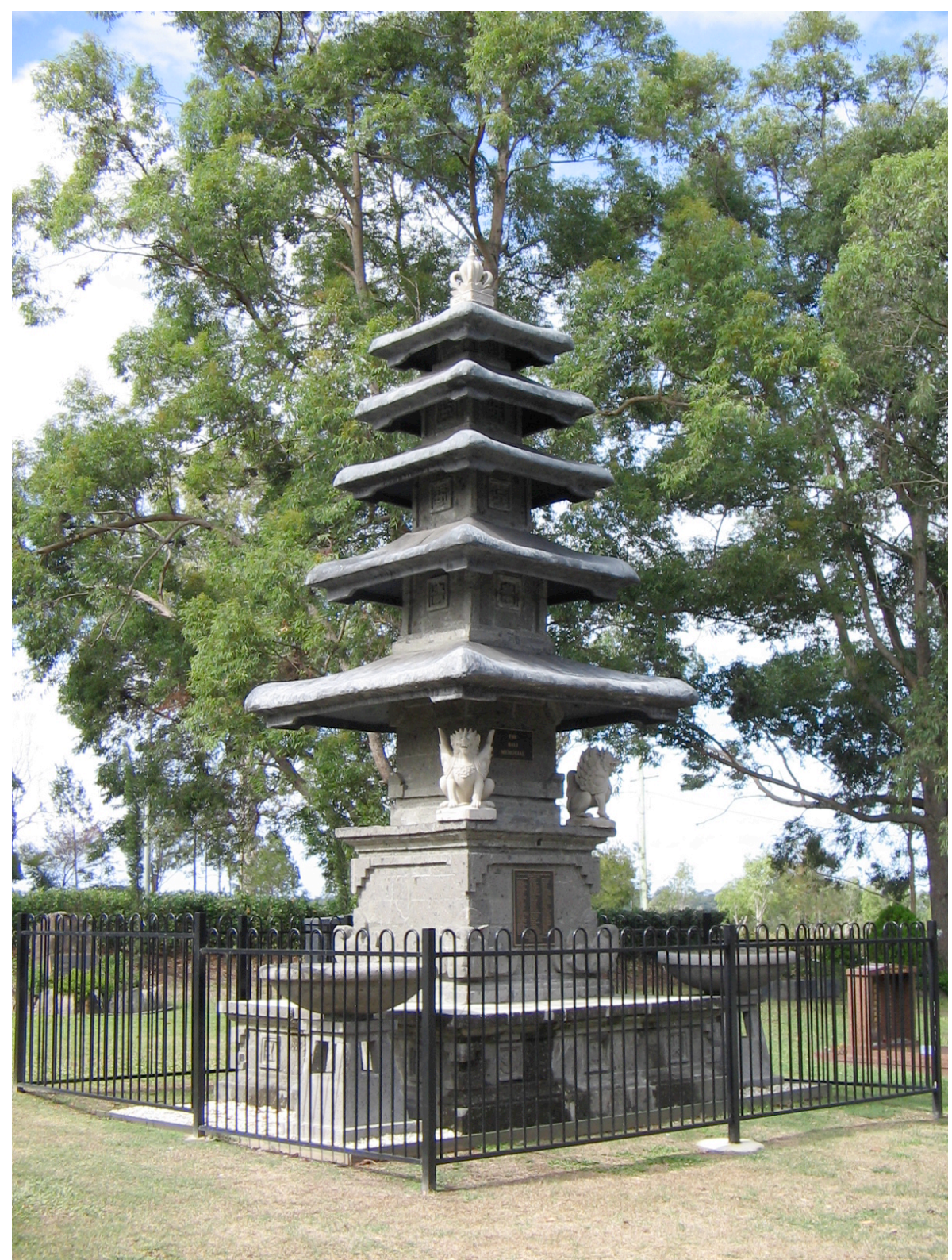

Bali memorial, Nerang Road, Broadbeach, Queensland, 2005 (Photograph Karyn Rendall)

Victorians.) On the first anniversary of the bombing, an imposing Balinese-style pegoda made in Bali was unveiled before a large gathering of people by Quentin Bryce, the Governor of Queensland, on Broadbeach Nerang Road in Nerang, Queensland. Both memorials attract mourners on each anniversary. ${ }^{18}$ The broader context that legitimized state involvement was the 'war against terror', launched 
after the September 112001 attacks on New York and Washington, in which Australia was a willing participant.

Memorial forms which arise from participatory memorialisation can also express forms of covert or overt opposition to government actions or oppositional understandings of the meaning of events. In Sydney, for example, an informal memorial to David Grundy, an Aboriginal man, was spray painted in red on the side wall of a terrace house in Abercrombie Street adjoining a park in the Sydney inner suburb of Redfern. Grundy had been killed in his home in Eveleigh Street in 1990 by shotgun wounds inflicted by members of the Special Weapons and Operations Section of the NSW police force. Police were searching for an escaped killer who had earlier shot two police officers and were raiding the homes of Aboriginal people in Redfern. The inscription reads:

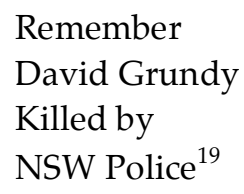

The injunction not to forget this needless death succinctly identifies who is responsible and keeps it alive for a community who have traditionally been excluded from power in Australian society. It links into a broader, established but unofficial narrative about police racism, brutality and corruption. Its location is also significant. Redfern is synonymous with Aboriginal radicalism, racial confrontation and violent clashes between police and Aborigines.

On the other hand, a different kind of 'counter' narrative emerges at an informal roadside memorial to Senior Constable Tony Clarke on a grassy verge along the Warburton Highway near Launching Place, Victoria. Clarke had been shot with his own gun after a struggle with a motorist on a lone patrol on 24 April 2005. He was the thirtieth police officer in Victoria to be murdered in the line of duty. ${ }^{20}$ Clarke was positioned as a 'victim' effectively depoliticizing his role as a representative of state authority (which in a sense he was). His death was framed in media releases and reportage in terms of a respectable, caring profession who put themselves at risk to serve and protect the community. The state government and the Victorian Police Association extended the process of memoralisation. After his funeral - which was attended by 1400 people including Steve Bracks, the Premier of 
Victoria, Tim Holding, the Minister of Police, Christine Nixon, the Victorian Chief Commissioner of Police and Mick Kealty, the Federal Police Commissioner - a new trauma theatre in the Alfred Hospital was dedicated to Clarke in Melbourne. In 2006 a Tony Clarke Memorial Day soccer match was established by the Victorian Police Soccer Club. ${ }^{21}$

Some memorials have caused a great deal of conflicting emotional responses. This has ranged from debates over the form of a fitting memorial to racing driver Peter Brock who died in a car crash in Western Australia on 8 September 2006 to incidents involving anti-war graffiti. The Brock memorial is unusual because the debate about the form of the memorial reflects conflict over who should have control of the memorialising. Brock's fans want to claim it for the popular - but what are the boundaries of 'good taste' or how sacred an object is a memorial? During the evening before Anzac Day in 2007, five teenage girls were arrested by police in Bathurst in central NSW after daubing the word 'murderers' in paint all over a war memorial that was to feature in the ceremonies. ${ }^{22}$ Reported across the country, the incident led to an amendment to that state's war memorial legislation which doubled the maximum penalty for acts of vandalism. Graffiti raises many issues and may become an even more vexed issue in the future. It involves ideas about the 'history of the present' which examines how the past is understood and remembered within contemporary consciousness. ${ }^{23}$ When is graffiti legitimate?

Mnemonic practices, like graffiti, express neither the past nor the present but the changing interactions between them. Counter memorials have also been created that eschew monumental status. And artists, designers and activists have in Australia and elsewhere, as Sue-Anne Ware notes, developed an anti-memorials movement that critiques 'the illusion that the permanence of stone somehow guarantees the permanence of the idea it commemorates' ${ }^{24}$ Others create fake memorial plaques claiming 'on this day in 1989, nothing happened' to resist the prevalent marking of an historical environment and the assumption of significance by authorities. There are also many instances where the absence of memorials speaks across the years. There are no memorials to Leigh Leigh in Newcastle, for example, though her rape and death in 1989 has been explored in the film Black Rock. There are also no physical memorials to Anita Cobby (though there is an internet site) or Janine Balding though her mother is campaigning for a generic memorial to those who die 


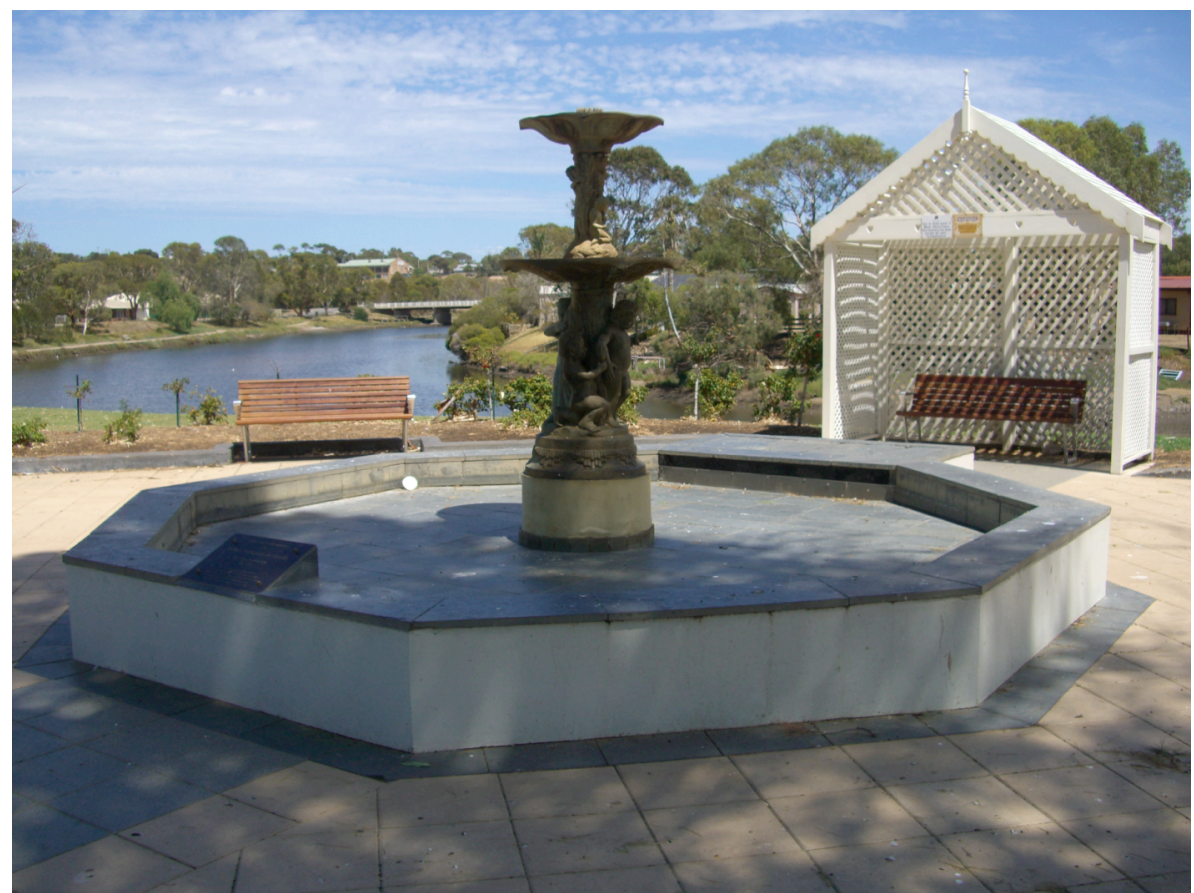

Memorial to Princess Diana, Market Square Reserve, Old Noralunga, South Australia, on the banks of the Onkaparinga River, 2008 (Photograph Paul Ashton)

violent deaths. There are obviously community ruptures here too powerful to be yet put to rest.

The contested and unstable nature of history has been the subject of much critical work in current historiography (especially as 'identity politics') and the focus of public debates about the past in Australian society. ${ }^{25}$ In terms of participatory memoralisation, there is wide though not well documented evidence of a determination by ordinary people in contemporary society to do the work of celebration or mourning by setting up memorials themselves. In the USA this was clearly expressed in the September 11 makeshift memorials and before this the more than a million gifts that were carried to the fences around the Oklahoma Bombing site. In Britain, and elsewhere, Princess Diana's sudden death generated a massive range of unofficial memorials left at the gates of the palace and her home. In Australia, Diana's death also prompted a number of formal, unofficial or semi-official memorials. On the banks of the Onkaparinka River in the small township of Old Noralunga in South Australia stands a memorial fountain dedicated to 'The People's Princess'. Popularly inspired but maintained by the local council, the memorial was unveiled by Sir Eric Neal, the Governor of 
South Australia, on 31 August 1998 on the first anniversary of Diana's death. On the same day in the small rural township of Panmure, in Victoria, the local Country Women's Association placed a small brass plaque beside a tree planting to 'Commemorate the life of Diane, Princess of Wales. ${ }^{26}$ In all of these instances, the state has played a role in shaping, accommodating or incorporating these acts of remembrance.

\section{Places of the Heart}

Places of the Heart is a national survey of non-war memorials that was conducted between late 2004 and early 2008. (Ken Inglis' study of Australian war memorials has greatly advanced field work on these memorials. ${ }^{27}$ Housed at the Australian Centre for Public History at the University of Technology, Sydney, the project developed a database of 378 memorials. Table 1 indicates the spread of these across the states and territories. The prominence of NSW in the sample was occasioned by two factors. Firstly, the project commenced as a NSW-based pilot study of 100 items which was folded into the larger survey. Secondly, initial and subsequent findings confirmed that there were no significant state or regional differences in the types of memorials, thus rendering proportional representation by states and territories a non-issue.

Table 2 shows the proportion of memorials in each thematic category devised by the project team. Memorials to natural and civil disasters, sudden death - including road fatalities - migrant and indigenous communities, animals and disease - such as AIDS - as well as personal memorials are self explanatory. Individual community role pertains to individuals who are remembered by communities for their various contributions. Community role relates to the memorialisation of collective roles that communities have played. These include memorials to emergency service workers, timber getters who opened up areas and started up an industry and organizations such as the Country Women's Association. Violation concerns memorials to those who have been murdered, raped or abused. The memorial to child sexual abuse in Hobart, Tasmania, is an example of the latter. Lost places (time) concerns memorials to places that have disappeared with the passage of time; lost places (state) to places that have been removed by official dictate.

Most common in the sample were memorials to the role played by individuals in their communities (129 out of 378 items or 34.12 per 
cent). This diverse category included people who had worked to secure amenities such as parks, reserves and community buildings, those who provided community services, local pioneers, municipal worthies and activists. The vast majority of these -85 memorials or 66 per cent of the 129 - were officially endorsed and all but a few of these were maintained by local, state or federal agencies. Many were financed by local government.

\section{SUDDEN DEATH}

Nationally and across all states and territories 'sudden death' was the second most recurrent theme in the Places of the Heart survey - 19.31 per cent overall relating to 73 items. Indeed, it is perhaps even more significant than these figures suggest since sudden death was also associated strongly with many of the memorials relating to civil disasters, natural disasters and the personal as well as the themes of violation and Indigenous community. (One distinction used to ascribe sudden death as the principal theme was the contemporaeity of memorials to the death.) While a variety of memorials fell under this theme - including a victim of shark attack in South Australia, a drowning in Nedlands in Western Australia and seven people killed in a suspicious fire that broke out in 'The Ghost Train' in 1979 in Sydney's Luna Park - one category that stands out is the now ubiquitous roadside memorial.

\section{ROADSIDE MEMORIALS}

our cars kill us, and without them we would die... ${ }^{28}$

The place of the automobile in the Australian culture and psyche has received much attention over the past two decades. Davison, for example, has treated the history of the car while Simpson has produced a solid account of the work in media and cultural studies on the impact of cars and car crashes on film. ${ }^{29}$ There has also been a growth in public interest and concern with roadside memorials in recent years. These have generated debate and a variety of official responses in both Australia and the United States but have received little attention to date from historians. Robert James, a folklorist, has identified major sites of memorialisation in northern $\mathrm{NSW}^{30}$ while a study of roadside memorials in Newcastle has been carried out by Hartig and Dunn. ${ }^{31}$ Work in the United States also indicates that 
Public History Review | Ashton \& Hamilton

Table 1

Places of the Heart Project

Memorials by State and Territory

$\begin{array}{lll}\text { State/Territory } & \text { No } & \% \\ \text { Australian Capital Territory } & 6 & 1.58 \\ \text { New South Wales } & 127 & 33.59 \\ \text { Northern Territory } & 64 & 16.93 \\ \text { South Australia } & 29 & 7.67 \\ \text { Tasmania } & 45 & 11.9 \\ \text { Queensland } & 25 & 6.61 \\ \text { Victoria } & 50 & 13.22 \\ \text { Western Australia } & 32 & 8.5\end{array}$

Total

378100

Table 2

Places of the Heart Project

Memorial Themes by Number and Per Cent

\begin{tabular}{lll} 
Theme & No & $\%$ \\
Natural Disaster & & \\
Civil Disaster & 21 & 5.55 \\
Sudden Death & 13 & 3.43 \\
Migrant community & 73 & 19.31 \\
Indigenous Community & 12 & 3.17 \\
Individual Community Role & 18 & 4.76 \\
Community Role & 129 & 34.12 \\
Violation & 40 & 10.58 \\
Lost Places (Time) & 2 & 0.52 \\
Lost Places (State) & 2 & 0.52 \\
Animals & 1 & 0.26 \\
Personal Memorials & 11 & 2.91 \\
Disease & 50 & 13.22 \\
Other & 4 & 1.05 \\
& 2 & 0.52 \\
\hline$\quad$ & & \\
\hline \multicolumn{1}{l}{ Total } & & \\
& 378 & 100 \\
\hline
\end{tabular}


roadside memorials have a long history involving cross-cultural entanglements. In the south-western states, the first roadside shrines appeared soon after Spanish invasion. ${ }^{32}$

When we began the groundwork for this study in 2002, however, there was very little official recognition of these memorials. A few relevant state government departments had informal policies. Some local government authorities indicated on their web sites that they had no specific objections to roadside memorials and that they would respect them by, among other things, not mowing over them in the course of roadside maintenance work. More recently, however, the situation has radically altered.

Despite some reductions in road carnage in the early twentieth century, between 1500 and 1800 people are killed in road accidents every year in Australia. Twenty-two thousand people are seriously injured..$^{33}$ Roadside memorials have proliferated over the past fifteen years. And there has been a diverse boom in official responses to this development. South Australia's Local Government Association (SALGA), for example, passed a resolution at its general meeting in March 2006 'to develop a state-wide policy, in consultation with the State Government' regarding the siting of memorials on road verges. ${ }^{34}$ The working group subsequently established to develop guidelines was sensitive to divided public opinion. The SALGA had received one piece of correspondence which asked 'why the entire nation... [was] expected to mourn these particular deaths'. But it was keenly aware of the demands of families in mourning to 'let us grieve at the scene' and the strong community support this sentiment commanded. ${ }^{35}$ Ultimately, the working group recommended guidelines that they considered compassionate, consistent and safe for motorists and others. But the memorials could not be permanent.

Tasmania's Department of Infrastructure, Energy and Resources (DIER) took a very different approach, tying guidelines for roadside crash markers into a land transport safety strategy. Black marker posts indicate fatalities; red markers signify serious injuries. Under this 'Roadside Crash Marker Program', the DIER provided the posts but local government authorities (LGAs) had to install the signage. These markers, however, were safety messages not memorials to specific individuals. The DIER noted that the 'installation of individual roadside monuments at crash sites is discouraged on 
Tasmanian roads. ${ }^{\prime 36}$ This system was adopted by other LGAs such as the City of Onkaparinga in South Australia. But it did not stifle the proliferation of personal roadside memorials. Three Tasmanian examples of these - at South Arm Highway, Deep Bay Road and Huon Road - are represented in the Places of the Heart database.

Mainroads Western Australia (MWA) issued a policy document and guidelines on roadside memorials towards the end of 2003. Commencing with the motto 'We respect your feelings', the MWA informed its public that it would approve the placement of these memorials; supply roadside memorials (up to the value of twenty dollars); and install or assist to install the memorial at appropriate places. The MWA would not, however, maintain or protect the memorials but they would 'remove any roadside memorials not conforming to this policy'. The policy included detailed specifications. Crosses were to be 'constructed from timber' and were to be ' $850 \mathrm{~mm}$ long $(600 \mathrm{~mm}$ out of the ground) and $400 \mathrm{~mm}$ wide', made 'from pieces $40 \mathrm{~mm} \times 18 \mathrm{~mm}^{\prime}$ and coated with a white, nonreflective paint. Proximities to sealed roads, guide posts and paths were stipulated as were places, such as landscaped verges, where they could not be located. Paver sizes and colours - grey only - were also specified as were particular native species if plants were to be part of the memorial. These varied for metropolitan and regional locations. Memorials were also to be 'without memorabilia such as artificial flowers, toys, pot plants, shoes [and]... clothing.' A 'Roadside Memorial Notice' for the removal of memorials in breech of the guidelines, including a five-year sunset clause, was appendicised. Removed memorials were stored for 60 days and destroyed if alternate arrangements were not made for them. ${ }^{37}$ Scores of local government authorities have similar - if less detailed guides. These are often overseen by council engineering branches. ${ }^{38}$

Various reasons may be ascribed to the impulse to memorialise a sudden death at the place where life was lost. At one level, these sites are deeply personal despite their public locations; they tragically inscribe personal meaning in space, turning vacant spots along roadsides into special places. And they can be seen as an alternative to more impersonal, modern cemeteries. 'Here', as Martha Norkunas argues, 'is the very absence of a body that is crucial to the moving of memory back into the heart of the community'. ${ }^{39}$ Some commentators have also pointed to a falling interest in mainstream religion and 'an 
increasing tendency to see spiritual authority resting with individual conscience' ${ }^{40}$

We have likewise noted elsewhere the impact of the decline of organised religion on practices such as genealogy that in part concern memorialisation and the escape of oblivion. ${ }^{41}$ Jennifer Clark and Majella Franzmann have observed that from 'the 1960s the authority of the state has also been questioned, leading to a general dissatisfaction with state control of what may be termed personal or moral matters, including the control of mourning in some way through policies regulating burial' ${ }^{42}$ This is particularly noticeable among youth. It is clear, however, from the policies and guidelines emanating from local government and other authorities, that in terms of roadside memorials the state continues to intervene in matters of mourning and memoralisation. Rules and regulations pertaining to roadside memorials can be compared to nineteenth and twentiethcentury cemeteries and public health acts that sought to control burials. $^{43}$

\section{TO LIST OR NOT TO LIST}

Heritage lists which have the force of law behind them - unlike National Trust or professional associations' listings - are among the principal mechanisms for ensuring a memorial's long-term survival. These include federal and state heritage list with statutory backing and Local Environment Plans, often referred to as LEPs, adopted by local government authorities. Having a place on an enforceable heritage list does not, however, mean that a memorial will be respected, conserved or preserved. To even be nominated for a listing, an item must have at least one champion - an individual, group, community or government agency. Generally, stringent criteria must be met for a memorial to be listed.

Heritage agencies are well aware of the impossibility of listing more than a fraction of the innumerable memorials that are scattered across the country. And it is impossible to save everything. Lisanne Gibson and Joanna Besley, in their major study of monuments in Queensland, dealt with 214 items, most of which were memorials. Of these, 47 (or 22 per cent) were listed on a heritage register; 167 (or 78 per cent) were not. ${ }^{44}$ Listing was more common in their study than ours where only 30 or approximately 8 per cent of memorials were heritage listed. Overall, however, it is clear that the vast majority of memorials are not protected on lists. But there is also a qualitative 
dimension to the making of lists. Thematic frameworks consciously or unconsciously adopted in the process of the identification and/or assessment of memorials for listing significantly shape their content.

In the Places of the Heart project, the most commonly listed memorials related to an individual's role in the community. This form of memorial is perhaps the most traditional and thus more restricted. Totalling 129 in number (just over one-third of the sample), they collectively tell a story which is essentially an antiquated version of Australian history with a touch of revisionism. Victoria has a memorial swimming pool to Prime Minister Harold Holt who drowned during an early morning swim at Cheviot Beach in 1967. In the Northern Territory there is a monument to George Knight who was the most senior government official in the nineteenth century. There is also a memorial in Elsy Cemetry to an Aboriginal woman, Dolly Bonson, who lived on Elsy Station near Mataranka in the Northern Territory, upon whom a character in the novel We of the Never Never was based. Unintentionally invoking the ideology of the 'dying race', wording on the plaque reads:

\author{
In memory of the last survivor \\ Of \\ We of the Never Never \\ Bett Bett \\ The Little Black Princess \\ Dolly Bonson \\ Who died in Darwin 3 March 1988 - aged 95 \\ She sleeps awaiting her Saviour's return \\ and the gift of eternal life. ${ }^{45}$
}

John Okey Davis (and wife) are remembered as the first settlers in the Gosnells district in Western Australia. Mokare, an Aboriginal man who promoted peace between blacks and whites, has a heritage-listed memorial in Albany, Western Australia. There is a listed memorial to Governor Arthur Phillip, the first governor of New South Wales, in the salubrious Sydney suburb of Gordon; a memorial garden to Jessie Street in Loftus Street, Sydney; and a memorial near the landing place where Edward Henty established the first European settlement in Victoria. Chilla Bulbeck has argued that to 'some extent, the recent history of Australian monument construction parallels the orientation 
of Australian history from the deeds that won empire or nation to the activities of ordinary men and women and the history of local communities' ${ }^{46}$ Her qualification is important since it is clear that many of these individuals were far from ordinary and that many monuments to individuals are linked into imperial or national stories and to the Australian identity. Further, official listings favour extraordinary people and larger narratives.

The theme concerning the collective role of communities was the second highest in terms of the number of heritage listed memorials in the Places of the Heart survey. Among these were the grand Miegunyah historic house in Queensland which is a memorial to women, particularly the pioneering variety; the South Australia Naval Memorial Garden, which has numerous types of memorials; and the Vlamingh memorial to the three Dutch ships that visited Western Australia in 1696. A bicentennial memorial to the first fleet was also unveiled by the Governor General, Sir Zelman Cowen, at Circular Quay in 1988. It was proposed and promoted by an elite genealogical association. Part of the plaque's lengthy working reads:

This memorial commemorates the voyage and arrival in Sydney of the first fleet which brought to Australia its first European settlers under the command of Captain Arthur Phillip, R. N. The fleet sailed from Portsmouth on 13th may 1787 and anchored in Sydney Cove at a spot just north of this memorial on 26th January $1788 \ldots$

The plinth of the memorial was donated by the Fellowship of First Fleeters, all of whom are direct descendants of those who arrived with the first fleet... ${ }^{47}$

A pattern emerges of 'discoveries' and exploration, pioneers and early settlers, governors and great men, romanticised views of Aboriginal people and their experiences. While this narrative may be antiquated, it is still officially dominant. Some heritage practitioners would argue that such a traditional view of Australian history is appropriate for heritage registers that seek to document a national past (or the pasts of the states and territories). As a whole, the collection of memorials in the Places of the Heart project demonstrate powerful themes in the nation's history which touch most people loss, the role that communities play in shaping their environments 
and the nation and the role of individuals, ordinary and otherwise, in shaping communities and lives. What we are suggesting here is the importance of types of memorials that have both personal and public significance across the country rather than individual memorials that are judged by experts on the basis of their 'national significance' whatever that may mean - or technical and aesthetic traits or rarity.

\section{A TALE Of Four Lists}

The limitations of official heritage lists are evident in an analysis of four heritage database lists - one federal and three state based represented in Table 3. An analysis of this table along with the Places of the Heart database reinforces the contention of Laurajane Smith, and others, that there is an authorised heritage discourse, evident in countries such as Australia, England, Canada and the USA, that is propagated by officially endorsed heritage agencies, both public and private. 'There is, really', Smith observes, 'no such thing as heritage... there is rather a hegemonic discourse about heritage, which acts to constitute the way we think, talk and write about heritage' ${ }^{48}$ This legitimises and reproduces old national narratives and social orders. In light of our discussion of retrospective commemoration and participatory memorialisation, however, we would contend, as Smith acknowledges, that this is a more complex process.

Table 3 reports the findings of the searches of the four selected heritage databases: the Federal Australian Heritage Database; the Victorian Heritage Register and Heritage Inventory; the New South Wales Heritage Office Local and State Government Agencies Listings; and the Heritage Council of Western Australia's Places Database. ${ }^{49}$ Each of the database search outcomes was examined thematically using the thirteen themes in the Places of the Heart survey. An initial reading of the results, however, indicated a dominance of war memorials, churches and church buildings and cemeteries so these themes were also included for general comparative purposes. In the final counting, of the 1524 listed items examined, 562 (or 36.9 per cent) were war memorials. While these comprised almost a quarter of federal listings (175 out of 721) almost half of New South Wales' listings were war memorials (167 out of 341) and they accounted for 55.6 per cent of Western Australia's memorials (194 out of 349).

After war memorials, churches were the next highest category on the listings (174 items or 11.4 per cent). This was followed by the role that individuals played in the community (112 or 7.3 per cent), 
cemeteries (60 or 4 per cent), memorials to collective community roles ( 36 or 2.3 per cent) and personal memorials ( 30 or 2 per cent). Thus 48.3 per cent of all listings related to war and churches. It might be contended that this is not surprising given the relatively broad time span - dating back to initial colonisation - covered by the listed heritage items. But the lists themselves were all created during the last three decades. In 1979, four years after the establishment of the Australian Heritage Commission, Professor Ray Whitmore, Chair of the Commission, bluntly noted that:

An interplanetary traveller landing in Queensland today and turning to the listings of the National Trust of Queensland or the Register of the National Estate for an appreciation of the life and achievements of her citizens since settlement would be presented with a strange picture. He would conclude that her forefathers lived in fine colonial homes, made banks and churches their principal monuments, invested in practically no public utilities, and hardly ever went to work..$^{50}$

The Queensland Heritage Act, which established that state's heritage register, was not passed until 1992. Western Australia's heritage act came into being during the previous year. Victoria's Historic Buildings (Amendment) Act was assented to in 1989. The current Victorian Heritage Register, however, was legislatively established in 1995. New South Wales's Heritage Act was assented to at the end of 1977, though its current state heritage inventory was not set up until the early 1990s.

It is not possible, or necessary, to directly compare and contrast the profiles of memorials generated by this heritage listing survey and the Places of the Heart survey due to their different purposes. Rather, it would be better to imagine what a history of Australia might look like if it drew primarily on the memorials in the federal and state heritage databases. This would certainly produce an 'official' history - a history endorsed by its subject, the nation state positive in tone with an underlying theme of progress. There would be few civil or natural disasters of any kind in such an account of the nation unless they highlighted unity in diversity and the indomitable Australian spirit. Migrant communities would be largely silent and Indigenous communities relegated to a brief mention and a footnote. Much Aboriginal heritage is registered on separate lists such as the 
Public History Review | Ashton \& Hamilton

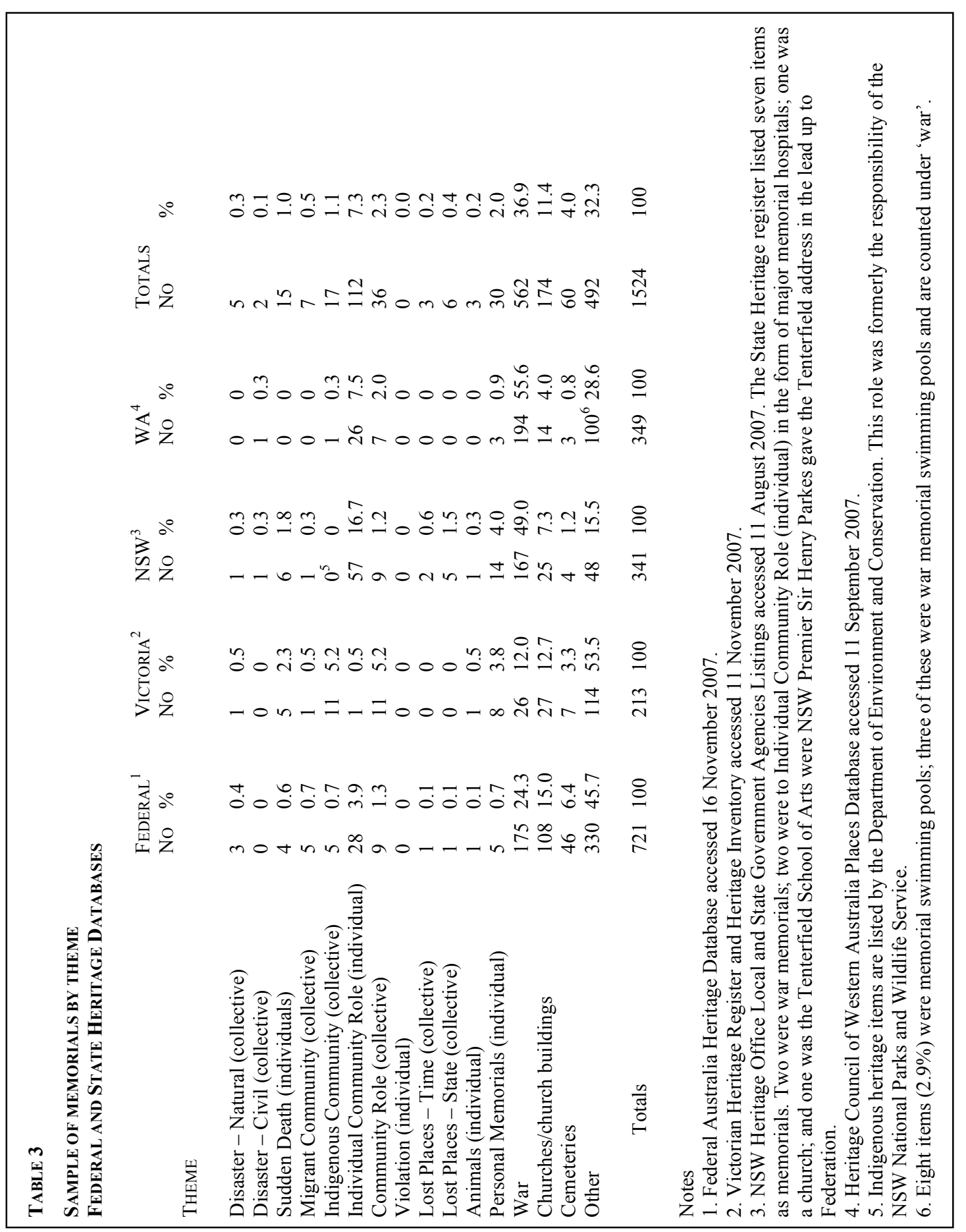


one for NSW formerly managed by the National Parks and Wildlife Service which is dominated by pre contact heritage and excludes places such as fringe camps and lockups. ${ }^{51}$ (Innovative work is being conducted, for example in the NSW Department of Environment and Climate Change's Culture and Heritage Unit, but this has yet to have major impacts. $)^{52}$ The role of individuals in community formation would form a theme but most of these people would be explorers, pioneers, politicians or people with property. Overall, this would be a history of the forging of a modern nation through sacrifice and the emergence of a masculine Australian identity.

\section{RETROSPECTIVE COMMEMORATION}

While formal heritage listings clearly privilege certain kinds of memorials over others, official versions of the past as expressed through memorials come under continuous pressures, subtle and otherwise, to adapt to cultural and social change, new knowledge or rediscovered pasts. Adaptations are more profound after periods of rapid change when the gap between official pasts and realities become untenable or when different groups become more powerful and are able to insert themselves into official histories. The latter process is about 'fitting in'.

On the Snowy Mountains Highway at Cooma in NSW there is a six metre high memorial to Tadeusz Kosciuszko. Stainless steel with a bust, its plaque in part reads:

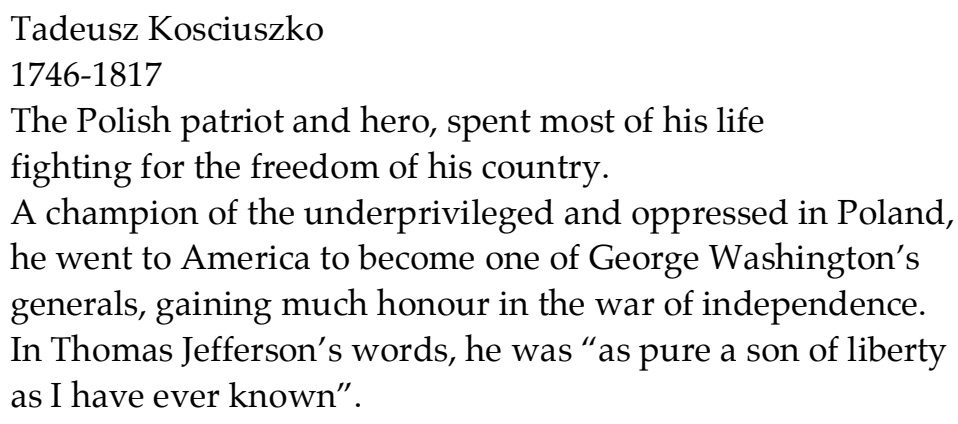

Polish explorer Count Paul Edmund Strzelecki named Mt Kociuszko in 1840. The plaque indicates that he also 'discovered' the mountain. The monument was raised by the Federal Council of Polish Associations in Australia 'as a gift to the people of Australia in the 
Bicentennial year 1988'. While commemorating the mountain's 'discovery' and naming, it is equally if not more concerned with remembering, as noted on the plaque, 'the contribution of Polish settlers to the Snowy Mountain Scheme.' Thus the monument links Polish Australians into the major founding myth of nation 'discovery' - and into the post World War II project of building modern Australia. Principal contributors, as listed on the plaque, were the Government of New South Wales, the Polish Association of New South Wales, the Major Stanslaw and Dr Maria Luk-Kozika Foundation, Maria and Henry Syriatowicz, Contal Co Pty Ltd, the Polish Associations in Newcastle and Hobart, the Polish ExServicemen's Association (sub-branch 3, Melbourne) and B. and K. Singler.

The Kosciuszko memorial might be considered a form of 'positive' revisionism. Polish people are here incorporated into a story of democratic nation building, not without struggle and suffering, but with progress for all as its ultimate outcome. Memorials such as this, which is now part of a heritage trail, tend to be untouched by vandals and do not attract calls for their removal. Far less able to be incorporated into official pasts, however, are shameful or forbidden histories. But when they are officially recognised, to whatever degree, these acts of 'negative' revisionism can be confronting and highly disturbing. They destabilise the historical foundations upon which a supposedly comfortable, tolerant and multicultural society rests. And they can confront individuals over their own pasts.

A nameless memorial was constructed on the lawns of Parliament House in Hobart, Tasmania, in December 2003. This is the place in the city were most protest meetings are conducted. Installed by Survivors Confronting Child Abuse and Rape Inc (SCCAR) and the Coalition Investigating Child Sex Abuse (CICSA), the memorial was intended to make people remember child sexual abuse in Tasmania and its ongoing occurrence. It comprises hundreds of white crosses, up to four deep, lining a hedge and flowerbed. Each day organisers add three crosses to represent the estimated number of children that are abused every day in Tasmania. A plastic sign indicates how many days the memorial has been in place and the number of crosses placed in the ground. (In mid January 2005 the memorial had been there for 304 days and 912 crosses had been planted.) The sign also says: 
Each cross represents one child abused in Tasmania every day since $3^{\text {rd }}$ December 2003. On that day the Bacon Government rejected a commission of inquiry into sexual assault against children. If you support this protest or want to talk about your own situation please call... ${ }^{53}$

The Greens Party had introduced a bill to investigate abuse in all areas except, for political reasons, the family. But the Labor Government and the Liberal Party opposition defeated the motion in parliament.

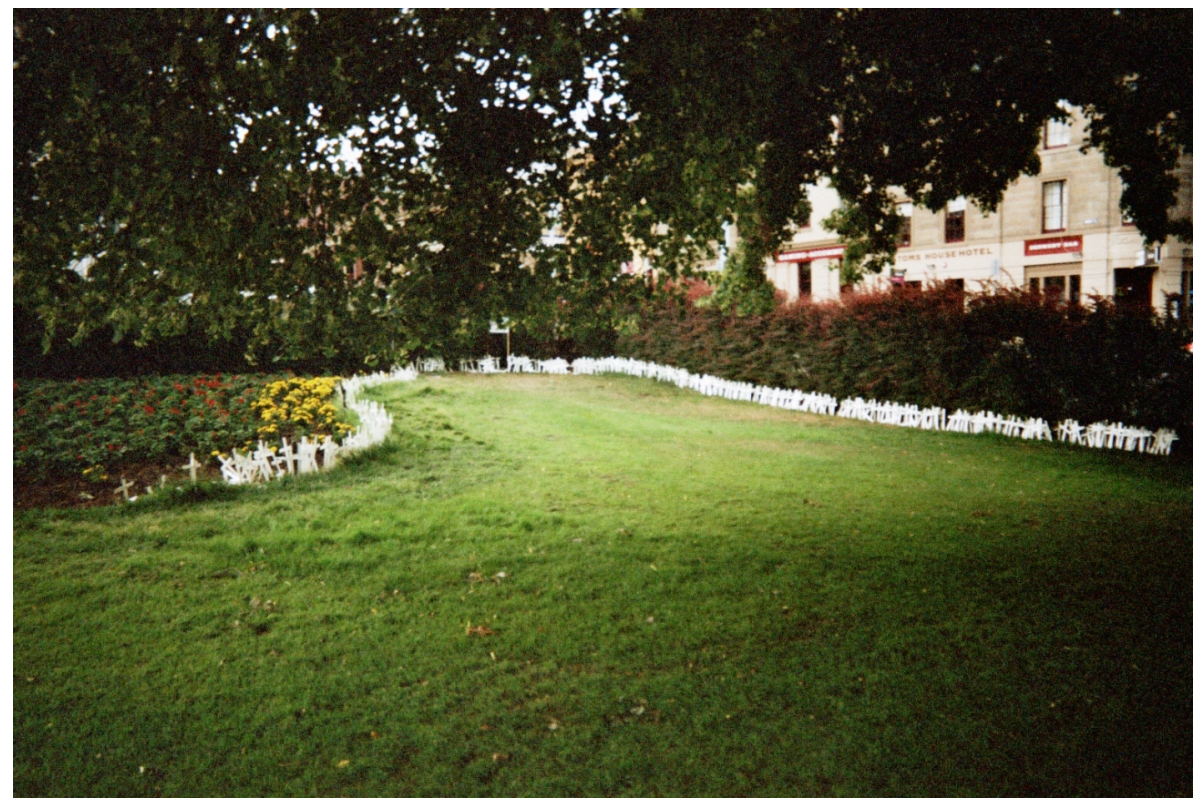

Memorial to victims of child abuse, Parliament House lawns, Hobart, 2005 (Photograph Caroline Evans)

This moving memorial provoked various responses. Notes and mementos have been discovered at the memorial. Someone placed a small cross made from scraps of plastic with tin foil angel wings among the other crosses. According to SCCAR President, Michael Longbottom, many visitors are comforted by the memorial. For one Sydney woman, however, the memorial hardened her resolve to commit suicide, though she later changed her mind about the memorial and taking her own life. The Speaker of the Tasmanian House of Parliament had another strong reaction to the monument. 


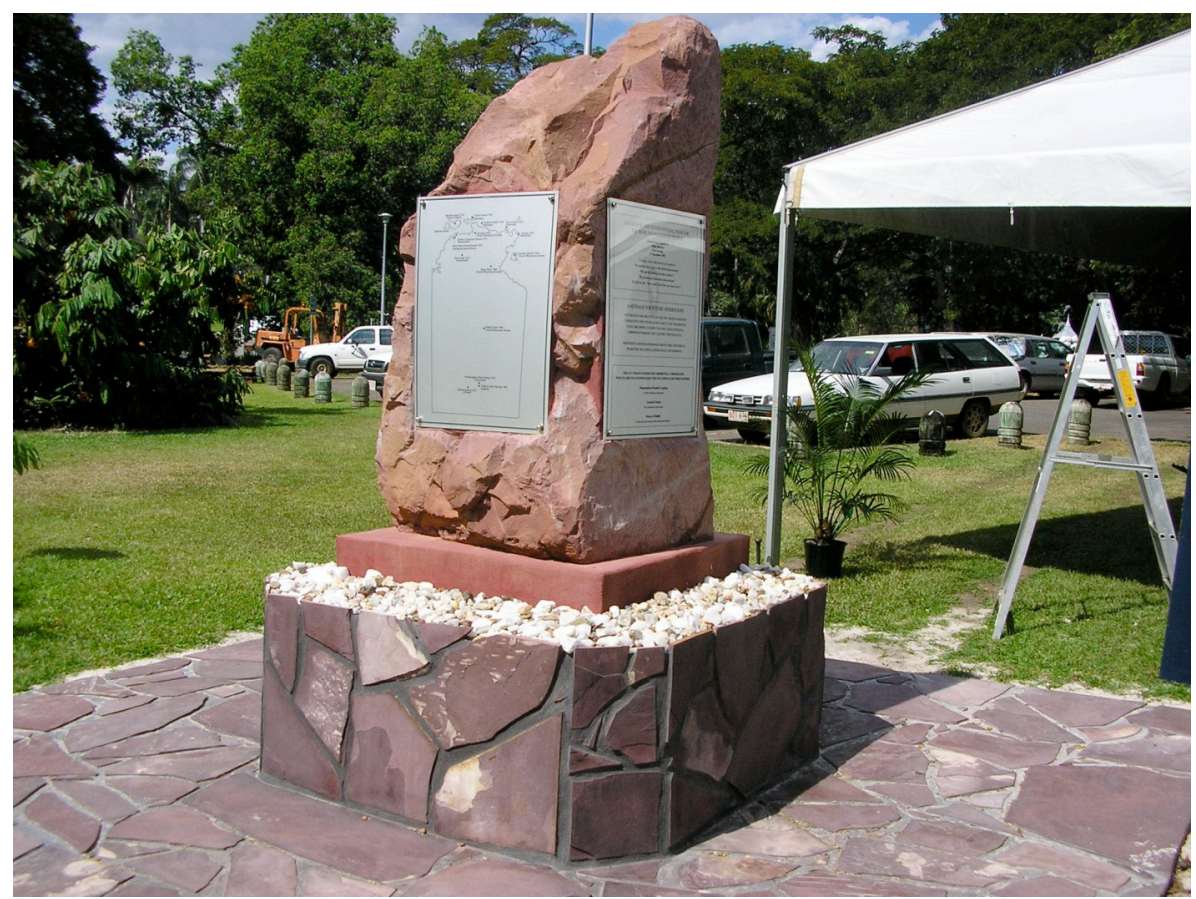

Stolen Generations memorial, George Brown Botanic Gardens, Darwin, 2005 (Photograph Bev Phetts)

At first he wanted it relocated to a position that completely obscured it from view. Subsequently, the Speaker wanted it removed. Michael Longbottom received an email from him indicating that the SolicitorGeneral considered the crosses 'a health hazard' and that they should be removed. And not long after the gardener began taking them away. Other similar emails followed but these stopped after the memorial received positive media coverage..$^{54}$

Taboos are infrequently incorporated into mainstream history. Indeed, sexual abuse is not dealt with in The Oxford Companion to Australian History. ${ }^{55}$ But burdens of historical knowledge can accumulate to a point where they cannot be ignored. This is starkly witnessed in the acknowledgement of the Aboriginal and Torres Strait Islander Stolen Generations, memorials to which are springing up across the country. One was unveiled in Darwin's Botanic Gardens in the Northern Territory on 30 July $2005 .{ }^{56}$ Highly visible, well maintained and frequently visited, this memorial materially inscribes the burden of needing to make this history publicly known. Its four large plaques provide a map indicating where the stolen children were taken in the Northern Territory; a detailed list of the 
legislation which bestowed powers to control and remove indigenous people; a message to future generations; an extract from a speech by Prime Minister Paul Keating acknowledging dispossession, discrimination, exclusion and the removal of children; and a four stanza poem which begins:

Mothers left with empty arms

Hearts broken, minds with no calm.

Children without an identity

Taken from their country. ${ }^{57}$

This memorial almost wails a history that had been suppressed or ignored for two generations; its abundance of text - both official and personal - says: 'This happened; you cannot ignore it'. But it took a significant report commissioned by the New South Wales Labor Government and produced in 1982 by historian Peter Read - who coined the term 'stolen generations' - and a \$1.5 million federal Labor government inquiry published in 1997 as Bringing Them Home involving testimonies from hundreds of Indigenous people - to have this history fully recognised..$^{58}$ These and other critical developments provided a context for other memorials such as the one off Shelly Beach Road in East Ballina, NSW, to the massacre of Bundjalung people at Black Head in 1853 or 1854. Unveiled on 11 August 2001, the memorial bears a plaque which has a lengthy description of the event, ending with the words:

Erected by a group of Aboriginal and non-Aboriginal Australians in an act of reconciliation, and acknowledgement of the truth of our shared history. ${ }^{59}$

\section{CONCLUSION}

Memorials as a form of public history allow us to chart the complex interactions and negotiations between officially endorsed historical narratives, public memorials, privately sponsored memorials in public spaces and new histories. As Ludmilla Jordanova reminds us, 'the state... lies at the heart of public history' ${ }^{60}$ And this is evident in the public process of memorialisation. At one level, the state endorses certain narratives within which communities and organisations need to operate if they are to be officially part of the national story and its regional and local variants. Ultimate endorsement for memorials 
includes listings on heritage registers. Controls over the erection of memorials vary from official policies to process for the issue of permits for their construction in public places or their removal.

The state, however, is not monolithic. Permissible pasts evolve over time given shifts in power and social and cultural change. The presence and power of the past in peoples' lives, too, means in practice that memorial landscapes will reflect, in truly democratic societies, the values, experiences and dominant concerns of its citizens.

\section{ENDNOTES}

${ }^{1}$ We would like to thank Kate Waters and Korey Moon who undertook extensive field work in New South Wales and who managed the bulk of the database. Field work was also undertaken by Caroline Evans, Bev Phetts, Maxine Pitts, Karyn Rendall and Kim Torney. We would finally like to acknowledge Rose Searby's work on the database and the project generally having taken over from Kate.

2 The difficulties of memorialising the Holocaust has an extensive literature. James Young writes eloquently about the inadequacy of traditional forms in The Texture of Memory: Holocaust Memorials and their Meaning, Yale University Press, 1993. See also Klaus Neumann, Shifting Memories: the Nazi Past in the New Germany, University of Michigan Press, 2000, for a more sophisticated understanding of how memory works in the form of antimemorials.

${ }^{3}$ David Glassberg, Sense of History: The Place of the Past in American Life, University of Massachusetts Press, 2001, chapter 2 'Remembering a War'; Jay Winter, Sites of Memory, Sites of Mourning: The Great War In European Cultural History, Cambridge University Press, London, 1995; Kristin Ann Hass, Carried to the Wall: American Memory and the Vietnam Veterans Memorial, University of California Press, 1998.

${ }^{4}$ The Miegunyah Press (MUP), Melbourne, 1998, pp243; 477.

${ }^{5}$ See Chilla Bulbeck, 'The Stone Laurel: Race, Gender and Class in Australian Memorials', Cultural Policy Studies, Occasional Paper no 5, Institute for Cultural Policy Studies, Griffith University, 1988 and Chilla Bulbeck, 'Aborigines, Memorials and the history of the Frontier', in John Rickard and Peter Spearritt (eds), Packaging the Past: Public Histories, special issue of Australian Historical Studies, April, 1991, pp168-78.

${ }^{6}$ This was published as Beryl Henderson (ed), Monuments and Memorials: A tribute to their worth, Royal Australian Historical Society, Sydney, 1988.

${ }^{7}$ Scates and Frances, op cit. They carried out this project with their students in Western Australia.

${ }^{8}$ Julie Stephens, 'Commemorating the SIEV X', Arena Magazine, 1 February 2008, p. 19.

${ }^{9}$ Victor Buchli and Gavin Lucas (eds), Archaeologies of the Contemporary Past, Routledge, London and New York, 2001, introduction to Part II, 'Remembering and Forgetting'. 
${ }^{10}$ Melanie van der Hoorn, 'Exorcising Remains: Architectural Fragments as Intermediaries between History and Individual Experience', Journal of Material Culture, vol 8, no 2, 2003, p189.

${ }^{11}$ Pierre Nora (Director) and Lawrence D. Kritzman (ed), Realms of Memory: The Construction of the French Past, vol 1 Conflicts and Divisions, vol 2 Traditions, vol 3 Symbols, Arthur Goldhammer (Trans), Columbia University Press, New York, 1996-98.

${ }^{12}$ Maoz Azaryahu 'The spontaneous formation of memorial space: The case of Kikar Rabin, Tel Aviv', Area, vol 28, no 4, pp501-13.

${ }^{13}$ See Bruce Scates and Ralene Frances, 'Honouring the Aboriginal Dead', Arena, 1994, pp36-45.

${ }^{14}$ See, for example, Laurajane Smith, Uses of Heritage, Routledge, Oxon, 2006, pp201; 203.

${ }^{15}$ See, for example, Chris Healy, From the Ruins of Colonialism: History as Social Memory, Cambridge University Press, Melbourne, 1997, part II, 'Installing Memory', pp77-129.

${ }^{16}$ The Age, 19 January 1997.

${ }^{17}$ Sydney Morning Herald, 18 January 2005. See item 339 in the Places of the Heart database.

${ }^{18}$ Places of the Heart database items 197; 42.

${ }^{19}$ Places of the Heart database item no 355.

20 'Memorial Dedication', The Police Association of Victoria Journal, March 2007, pp16-19. Mark Bailey, a mentally ill 27-year-old who was suspected of the murder, committed suicide. See also The Age, 29 April 2005.

${ }^{21}$ Victoria Police, media release, 12 June 2007.

${ }^{22}$ Sydney Morning Herald 25 April 2007; The Age, 25 April 2007.

${ }^{23}$ For example, see Susannah Radstone (ed) Memory and Methodology, Berg Oxford and New York, 2000; Mieke Bal, Jonathan Crewe and Leo Spitzer (eds) Acts of Memory: Cultural Recall in the Present. Dartmouth College, University Press of New England, 1999.

${ }^{24}$ Sue-Anne Ware, 'Contemporary Anti-Memorials and National Identity in the Victorian Landscape', Journal of Australian Studies, vol 81, 2004, p121.

${ }^{25}$ See, for example, Stuart Macintyre and Anna Clark, The History Wars, Melbourne University Press, Melbourne, 2003.

${ }^{26}$ Places of the Heart database items 373; 328.

${ }^{27}$ Inglis, op cit.

${ }^{28}$ Elizabeth Jacka and Susan Dermody, The Screening of Australia, Currency Press, Sydney, 1988, p113.

${ }^{29}$ Graeme Davison with Susan Yelland, Car Wars: How the Car Won our Hearts and Conquered our Cities, Allen and Unwin, Sydney, 2004; Catherine Simpson, 'Antipodean Automobility and Crash: Treachery, Trespass and Transformation of the Open Road', Australian Humanities Review, issue 3940, September 2006, np.

${ }^{30}$ Robert James, 'Roadside Memorials: some Australian examples', Folklore, vol 110, 1999, pp.103-5.

${ }^{31}$ K.V. Hartig and K.M. Dunn, 'Roadside Memorials: Interpreting New Deathscapes in Newcastle, New South Wales', Australian Geographical Studies, vol 36, no 1, 1998, pp5-20. See also George Monger, 'Modern Wayside Shrines', Folklore, vol 108, 1997, pp113-4.

${ }^{32}$ Holly Everett, 'Roadside crosses and memorial complexes in Texas', Folklore, vol 111, no 1, 2000, pp99-103. 
${ }^{33}$ Australian Bureau of Statistics, Year Book of Australia, 2006 publication number 1301.0.

${ }^{34}$ Local Government Association of South Australia, Temporary Roadside Memorials, Adelaide, September 2006, p1.

${ }^{35}$ ibid, p. 2. The report cited an article in the Adelaide Advertiser, 11 June 2006, 'Dad's road tribute plea, let us grieve at the scene'.

${ }^{36}$ DIER, Technical Advice Sheet, no 7, p 4.

${ }^{37}$ Mainraods Western Australia, 'Roadside Memorials Policy and Guidelines' document no 45/01/01, issued October 2004.

${ }^{38}$ For example, see Forbes Shire Council, 'Roadside Memorials Policy', policy no ETS.001, 21 September 2006.

${ }_{39}$ Martha Norkunas, Monuments and Memory: History and representation in Lowell Massachusetts, Smithsonian Institute, Washington, 2002, p183.

${ }^{40}$ Jennifer Clark and Magella Franzmann, "“A father, a son, my only daughter": Memoralizing Road Truma', Roadwise, no 13, pp4-5. See also Jennifer Clark and Majella Franzmann, 'Authority from Grief, Presence and Place in the Making of Roadside Memorials', Death Studies, vol 30, no 6, 2006, pp579-99.

${ }^{41}$ Paul Ashton and Paula Hamilton, 'Connecting with history: Australians and their pasts', in Paula Ashton and Hilda Kean (eds), People and Their Pasts: Public History Today, forthcoming Palgrave Macmillan, London, 2008.

${ }^{42}$ Clark and Franzmann, 'A father...', op cit.

${ }^{43}$ See, for example, Stefan Petrow, 'God's neglected acres: cemeteries in Tasmania 1803-1992', Public History Review, vol 2, 1993, pp144-67.

${ }^{44}$ Lisanne Gibson and Joanna Besley, Monumental Queensland: signposts on a cultural landscape, University of Queensland Press, St Lucia, 2004, pp237-44.

${ }^{45}$ Places of the Heart database item 152.

${ }^{46}$ Chilla Bulbeck, 'Australian history set in concrete', Journal of Australian Studies, vol 28, no 3, 1991, p4.

${ }^{47}$ Places of the Heart database, text entry for item 313.

${ }^{48}$ Laurajane Smith, op cit, p11.

${ }^{49}$ The federal database was chose to give a general national spread; the New South Wales database due to one third of the Places of the Heart memorials coming from that state; Victoria because it is the second most populus state; and Western Australia because of its large geographical size and relatively small population.

${ }^{50}$ Ray Whitmore, 'Our engineering heritage', Institute of Engineers Australia (Queensland Division), Technical Papers, vol 20, no 6, April 1979, quoted in Australia's National Estate: The role of the Commonwealth, Australian Heritage Commission Special Heritage Publication Series, no 1, Australian Government Publishing Service, Canberra, 1985, p126.

${ }^{51}$ See, for example, Denis Byrne, 'The Archaeology of Disaster', Public History Review, vol 5/6, 1996-7, pp17-29.

${ }^{52}$ See, for example, Denis Byrne, Helen Brayshaw and Tracy Ireland, Social Significance: A discussion paper, NSW National Parks and Wildlife Service, Sydney, 2001.

${ }^{53}$ Caroline Evans undertook the detailed field work for this memorial. Thanks to Michael Longbottom, SCCAR President, for his assistance.

${ }_{54}$ 'Child Sexual Abuse Memorial to Victims', file, Australian Centre for Public History. Much of this detail is taken from an interview between Caroline Evans and Michael Longbottom, 14 January 2005. 
${ }^{55}$ Graeme Davison, John Hirst and Stuart Macintyre (eds), The Oxford Companion to Australian History, OUP, Melbourne, 1998.

${ }^{56}$ Northern Territory News, 29 July 2995. Thanks to Bev Phelts for the detailed recording of this memorial.

${ }^{57}$ Places of the Heart database item 154.

${ }^{58}$ The Bringing Them Home report is available at www.auslii.edu.au/au/special/rsproject/rsilibrary/hreoc/stolen/.

${ }^{59}$ Places of the Heart database item 27.

${ }^{60}$ Ludmilla Jordanova, History in Practice, Arnold, London, 2000, p155. 